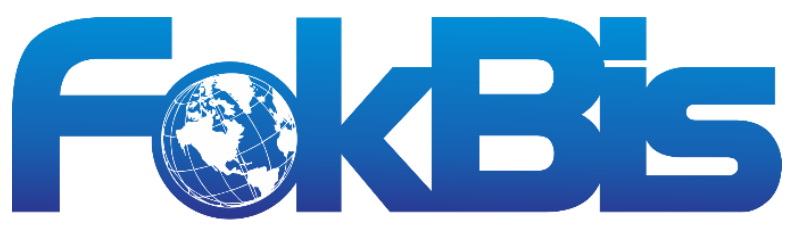

Media Pengkajaan Manajemen dan Akuntansi

http://journal.stieputrabangsa.ac.id/index.php/fokbis/index

ISSN: 2623-2480/ P-ISSN: 1693-5209

\section{Menyelamatkan Usaha Mikro, Kecil dan Menengah dari Dampak Pandemi Covid-19}

\author{
Dani Sugiri \\ Politeknik Keuangan Negara STAN \\ email: danisugiri@pknstan.ac.id
}

\section{Article Information}

\section{History of Article:}

Received: May $31^{\text {st }} 2020$

Accepted: June $19^{\text {th }} 2020$

Published: July $31^{\text {st }} 2020$

\section{DOI:}

10.32639/fokusbisnis.v19i1.575

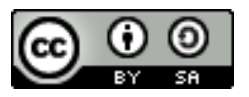

\begin{abstract}
ABSTRAK
Pemerintah telah melakukan berbagai upaya penyelamatan Usaha Mikro, Kecil dan Menengah (UMKM) dari dampak pendemi COVID-19. Tujuan penelitian ini adalah memetakan kebijakan pemerintah dalam memperkuat UMKM tersebut serta memetakan strategi jangka pendek dan jangka panjang yang diperlukan sebagai pelengkap kebijakan tersebut. Penelitian menggunakan metode kualitatif. Penelitian menggunakan data sekunder yang berasal dari berbagai literatur seperti buku-buku, artikel, serta homepage untuk mengakses data dan informasi terkini berkaitan dengan kebijakan penyelamatan UMKM dari dampak pandemi COVID-19. Teknik analisis dilakukan dengan analisis deskriptif. Berdasarkan penelitian, diketahui bahwa keberhasilan kebijakan penyelamatan UMKM dari dampak pandemi COVID-19 perlu didukung dengan strategi jangka pendek dan strategi jangka panjang untuk menjaga kesinambungan UMKM sebagai salah satu pelaku perekonomian Indonesia.
\end{abstract}

Kata Kunci: Pandemi COVID-19; UMKM; Insentif Pajak; Relaksasi Kredit; Bantuan Modal

\begin{abstract}
The government has made various efforts to save Micro, Small and Medium Enterprises (MSMEs) from the effects of the COVID-19 epidemic. The purpose of this study is to map government policies in strengthening the MSMEs as well as mapping the short-term and long-term strategies needed to complement these policies. Research using qualitative methods. The research uses secondary data from various literatures such as books, articles, and homepages to access the latest data and information related to the MSME rescue policy from the impact of the COVID-19 pandemic. The analysis was done by descriptive analysis. Based on research, it is known that the success of MSME rescue policies from the impact of the COVID-19 pandemic needs to be supported by short-term and long-term strategies to maintain the sustainability of MSMEs as one of the economic agents of Indonesia.
\end{abstract}

Keywords: COVID-19 Pandemic, SMEs, Tax Incentives, Credit Relaxation, Capital Assistance 


\section{PENDAHULUAN}

COVID-19 telah menjadi masalah global dunia termasuk di Indonesia. Sampai dengan tanggal 30 Mei 2020, pasien terinfeksi COVID-19 seluruh negara mencapai 6 juta lebih dengan angka kematian per 1 juta penduduk sebesar 47 orang (Wordometer, 2020). Tabel 1 menyajikan data pasien terinfeksi COVID19 terbesar di dunia dan Indonesia. Apabila dilihat berdasarkan data tersebut, Indonesia menempati posisi ke-32 dunia untuk total kasus pasien terinfeksi COVID-19.

Tabel 1. Data Pasien Terinfeksi COVID-19 Terbesar di Dunia

\begin{tabular}{llllll}
\hline No & Negara & $\begin{array}{l}\text { Total } \\
\text { Kasus }\end{array}$ & Meninggal & $\begin{array}{l}\text { Jumlah } \\
\text { Penduduk }\end{array}$ & $\begin{array}{l}\text { Kematian / 1 } \\
\text { Juta } \\
\text { Penduduk }\end{array}$ \\
\hline & Dunia & 6.023 .032 & 366.372 & 7.794 .798 .739 & 47 \\
1 & Amerika Serikat & 1.792 .822 & 104.523 & 330.827 .597 & 316 \\
2 & Brasil & 466.200 & 27.923 & 212.422 .152 & 131 \\
3 & Rusia & 387.623 & 4.374 & 145.928 .996 & 30 \\
4 & Spanyol & 285.644 & 27.121 & 46.753 .197 & 580 \\
5 & Inggris & 271.222 & 38.161 & 67.853 .964 & 562 \\
6 & Italia & 232.248 & 33.229 & 60.469 .504 & 550 \\
7 & Perancis & 186.835 & 28.714 & 65.260 .761 & 440 \\
8 & Jerman & 183.019 & 8.594 & 83.760 .156 & 103 \\
9 & India & 173.491 & 4.980 & 1.378 .752 .175 & 4 \\
10 & Turki & 162.120 & 4.489 & 84.254 .857 & 53 \\
32 & Indonesia & 25.216 & 1.520 & 273.255 .522 & 9 \\
\hline
\end{tabular}

Sumber: BNPB (2020) dan Wordometer (2020).

Pandemi COVID-19 memberikan implikasi ekonomi, sosial, dan politik hampir di seluruh negara, termasuk di Indonesia (Susilawati, Falefi, \& Purwoko, 2020) dan (Pakpahan, 2020). The World Trade Organisation (WTO) memperkirakan bahwa volume perdagangan dunia secara global kemungkinan akan menurun sekitar 32\% pada tahun 2020 selama masa COVID-19 (Islam, 2020). Pembatasan aktivitas masyarakat sebagai upaya penanganan pandemi COVID-19 telah menimbulkan kerugian ekonomi yang signifikan secara nasional (Hadiwardoyo, 2020). Sektor yang terkena dampak selama pandemi COVID-19 adalah transportasi, pariwisata, perdagangan, kesehatan dan sektor lainnya, tetapi sektor ekonomi yang paling terpengaruh oleh COVID-19 adalah sektor rumah tangga (Susilawati et al., 2020). Sedangkan menurut OECD (2020) dan Febrantara (2020) sektor usaha yang mendapatkan dampak signifikan adalah pariwisata dan transportasi.

Dampak ekonomi akibat pandemi COVID-19 juga dirasakan sektor Usaha Mikro, Kecil, dan Menengah (UMKM). Hal ini karena UMKM menempati posisi yang strategis dalam perekonomian secara umum. Di ASEAN, UMKM menghasilkan lapangan kerja antara 50\% s.d. 95\%, dan berkontribusi antara 30\% s.d. 50\% terhadap GDP (Islam, 2020). Indonesia sendiri, UMKM merupakan salah satu sektor strategis dalam perekonomian nasional yang dapat dilihat dari penyerapan tenaga kerja (Abidin, 2015). Usaha kecil termasuk yang paling terpukul oleh krisis COVID-19, banyak yang menutup usaha sementara waktu, dan lebih jauh lagi menghadapi kendala arus kas (Baker \& Judge, 2020).

OECD (2020) sendiri menyebutkan bahwa UMKM saat ini berada dalam pusat krisis ekonomi akibat pandemi COVID-19, bahkan dengan kondisi lebih parah dari krisis keuangan 2008. Krisis akibat pandemi akan berpengaruh pada UMKM dengan risiko serius dimana lebih dari 50\% UMKM tidak akan bertahan beberapa bulan ke depan. Ambruknya UMKM secara luas dapat berdampak kuat pada nasional ekonomi dan prospek pertumbuhan global, pada persepsi dan harapan, dan bahkan pada sektor keuangan, 
mengingat 60-70\% lapangan kerja di negara OECD diperankan oleh UMKM dan terlebih dari itu terdapat tekanan oleh portofolio yang tidak memiliki kinerja. Kemunduran situasi keuangan UMKM dapat memiliki efek sistemik pada sektor perbankan secara keseluruhan (OECD, 2020).

Menurut Febrantara (2020) dan OECD (2020), dampak pandemi COVID-19 kepada UMKM dapat dilihat dari sisi penawaran dan sisi permintaan. Dari penawaran, dengan adanya pandemi Covid-19, banyak UMKM mengalami kekurangan tenaga kerja. Hal tersebut terjadi karena alasan menjaga kesehatan pekerja dan adanya pemberlakuan pembatasan sosial (social distancing). Kedua sebab tersebut berujung pada keengganan masyarakat untuk bekerja sementara waktu pandemi masih ada COVID-19. Pada sisi permintaan, berkurangnya permintaan akan barang dan jasa berdampak pada UKM tidak dapat berfungsi optimal yang berujung pada berkurangnya likuiditas perusahaan. Hal ini menyebabkan masyarakat kehilangan pendapatan, karena UKM tidak berkemampuan membayar hak upah pekerja. Pada kondisi terburuk, pemutusan hubungan kerja terjadi secara sepihak.

Lebih dari 106 negara telah mengenalkan atau mengadopsi program perlindungan sosial serta intervensi pasar tenaga kerja sebagai respons atas COVID-19 (Gentilini, Almenfi, Orton, \& Dale, 2020). Umumnya setiap negara melakukan bauran kebijakan untuk tetap menjaga agar sektor UMKM telah dapat bertahan selama pandemi dan setelah pandemi COVID-19.

Penelitian ini bertujuan untuk mendeskripsikan kebijakan pemerintah dalam menyelamatkan UMKM dari dampak pandemi COVID-19 di Indonesia. Selain itu, penelitian dimaksudkan untuk memberikan gambaran mengenai strategi apa yang dapat ditempuh sebagai pelengkap kebijakan tersebut.

Setelah melakukan studi literatur dan observasi terhadap berbagai kebijakan pemerintah untuk menyelamatkan sektor UMKM, maka dapat dikatakan bahwa penelitian yang dilakukan oleh penulis adalah penelitian yang memiliki unsur kebaruan dan orisinalitas. Penelitian ini juga masih tergolong langka, karena memotret kebijakan terkini, sehingga dapat diajukan sebagai kerangka acuan dan atau pemantik untuk penelitian selanjutnya.

\section{KAJIAN LITERATUR}

\section{Usaha Kecil Mikro dan Menengah (UMKM)}

Menurut Undang-Undang Nomor 20 Tahun 2008, Usaha Kecil dan Menengah (UKM) adalah jenis usaha kecil yang memiliki kekayaan bersih paling banyak Rp200.000.000 tidak termasuk tanah dan bangunan tempat usaha. Dan usaha yang berdiri sendiri. Untuk selanjutnya dalam tulisan ini, UKM akan dipersamakan dengan UMKM.

Indonesia yang didominasi oleh Usaha Mikro, kecil, dan Menengah (UMKM) perlu memberikan perhatian khusus terhadap sektor ini karena kontribusi UMKM terhadap perekonomian nasional yang cukup besar (Pakpahan, 2020). Setidaknya terdapat tiga peran UKM yang sangat penting dalam kehidupan masyarakat kecil yakni sarana mengentaskan masyarakat dari jurang kemiskinan, sarana untuk meratakan tingkat perekonomian rakyat kecil, memberikan devisa bagi negara (Prasetyo \& Huda, 2019).

Pada tahun 2018 terdapat 64.194.057 UMKM yang ada di Indonesia (atau sekitar 99 persen dari total unit usaha) dan sektor UMKM juag telah mempekerjakan 116.978.631 tenaga kerja atau sekitar 97 persen dari total tenaga kerja di sektor ekonomi (Kemenkop-UKM, 2018). Pada tahun 2018, UMKM menyumbang PDB atas dasar harga berlaku sebesar 61,07\% secara nasional (Kemenkop-UKM, 2018). Grafik 1 menyajikan perkembangan UMKM di Indonesia sejak tahun 2010 sampai dengan 2018. UMKM di Indonesia mengalami kenaikan dari tahun ke tahun (Databoks, 2020). 


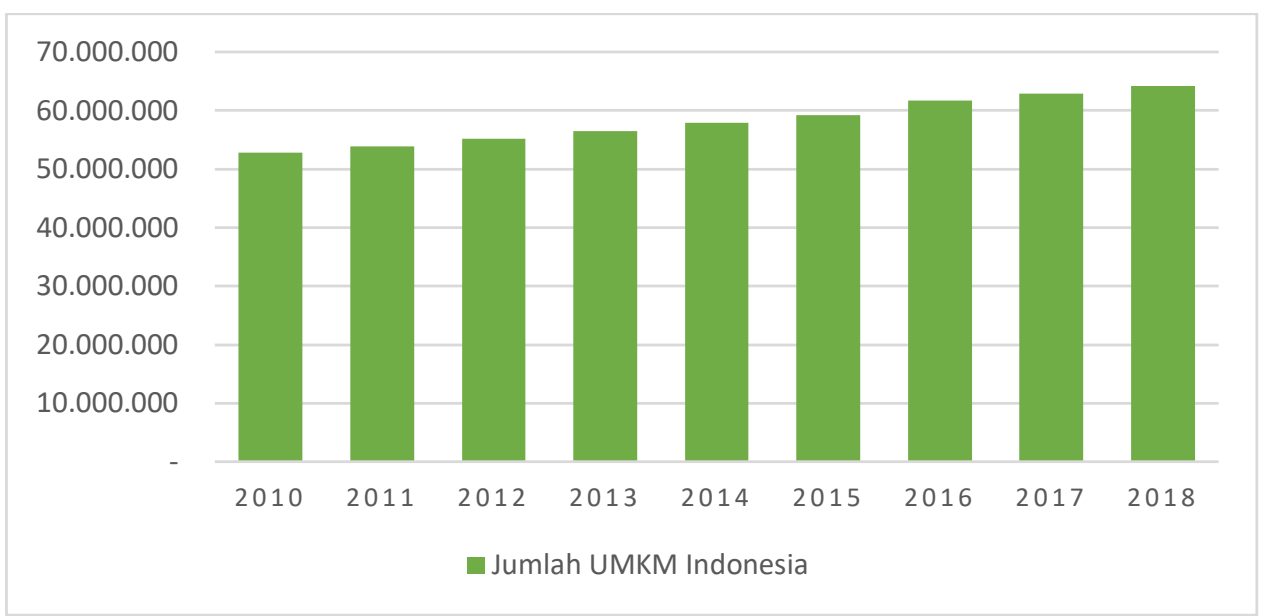

Grafik 1. Perkembangan UMKM di Indonesia Tahun 2010-2018

\section{Dampak Pandemi pada UMKM di Indonesia}

Indonesia adalah salah satu negara yang terdampak terutama pada sisi ekonomi (Pakpahan, 2020). Pandemi Covid-2019 membawa berbagai dampak pada perekonomian seperti terjadi kesusahan dalam mencari lapangan pekerjaan, susah untuk memenuhi kebutuhan hidup sehari-hari, tidak mempunyai penghasilan dalam memenuhi kebutuhan untuk sehari-hari dan juga banyak kesusahan yang di terima dari semua sektor perekonomian dalam semua bidang juga merasakan dampak dari Covid-19 (Hanoatubun, 2020).

Sampai dengan 17 April 2020, sebanyak 37.000 pelaku UMKM melaporkan diri kepada Kementerian Koperasi dan UKM terdampak pandemi COVID-19 (Setiawan, 2020b). Menurut rilis data tersebut, kesulitan yang dialami oleh UMKM selama pandemi itu terbagi dalam empat masalah. Pertama, terdapat penurunan penjualan karena berkurangnya aktifitas masyarakat di luar luar sebagai konsumen. Kedua, kesulitan permodalan karena perputaran modal yang sulit sehubungan tingkat penjulan yang menurun. Ketiga, adanya hambatan distribusi produk karena adanya pembatasan pergerakan penyaluran produk di wilayah-wilayah tertentu. Keempat, adanya kesulitan bahan baku karena sebagai UMKM menggantungkan ketersediaan bahan baku dari sektor industri lain. Tabel 2 memperlihatkan bahwa dari keempat persoalan tersebut, dampak penurunan penjualan menjadi persoalan terbesar yang dirasakan oleh pelaku UMKM. Dampak pandemi terhadap UKM diyakini dapat lebih besar, karena tingginya tingkat kerentanan dan minimnya ketahanan akibat keterbatasan sumber daya manusia, supplier, dan opsi dalam merombak model bisnis (Febrantara, 2020).

Tabel 2. Dampak COVID-19 ke UMKM

\begin{tabular}{ll}
\hline Dampak & Persentase (\%) \\
\hline Penurunan Penjualan & 56,0 \\
Kesulitan Permodalan & 22,0 \\
Hambatan distribusi produk & 15,0 \\
Kesulitan bahan baku & 4,0 \\
\hline
\end{tabular}

Sumber: Setiawan (2020b) dan Kemenkop-UKM (2020)

\section{Upaya Pemerintah Menyelamatkan UMKM di Indonesia}

Beberapa literatur dalam digunakan untuk menelusuri berbagai arah dan kebijakan yang dilakukan oleh pemerintah Indonesia dalam melindung UMKM dari dampak pandemi COVID-19. Pemerintah Indonesia perlu melakukan berbagai upaya untuk membantu ekonomi masyarakat melalui berbagai kebijakan (Susilawati et al., 2020). Keberhasilan kebijakan pemerintah tersebut, sangat tergantung dengan dukungan komponen pelaku usaha di masyarakat. Masyarakat dan pemerintah harus bersama-sama melindungi perekonomian dari dampak Covid-19 (Hanoatubun, 2020). 
Kebangkitan UMKM pasca COVID-19 sangat membutuhkan dukungan dan semua pemangku kepentingan. Sebagai contoh, untuk sektor pariwisata mitra perjalanan bisnis, agen perjalanan, perhotelan, lembaga pendidikan, lembaga keuangan, komunitas lokal, asuransi dan dari kerjasama dengan industri sejenis (Hadi, 2020). Hadi (2020) merekomendasikan bahwa kebijakan revitalisasi UMKM dilakukan dengan meningkatkan sinergi antar program dan antar lembaga pemerintah, memperbanyak ragam upaya promosi secara modern produk UMKM ke pasar domestik dan ekspor, pemberlakuan kebijakan kredit dengan suku bunga yang rendah dan proses sederhana, serta mendorong peningkatan sarana pendukung UMKM dan kreativitas UMKM agar berdaya saing tinggi.

\section{METODE}

Penelitian ini menggunakan metode kualitatif deskriptif dengan memanfaatkan data sekunder yang berasal dari berbagai literatur seperti buku-buku, artikel, serta homepage untuk mengakses data dan informasi terkini berkaitan dengan kebijakan penyelamatan UMKM dari dampak pandemi COVID-19. Penggunaan metode kualitatif deskriptif bertujuan untuk memberikan deskripsi serta mendapatkan gambaran yang jelas yang berguna untuk menjawab rumusan masalah, yaitu mengenai bagaimana kebijakan pemerintah dalam menyelamatkan UMKM dari dampak pandemi COVID-19 serta strategi apa yang dapat ditempuh sebagai pelengkap kebijakan tersebut.

\section{HASIL DAN PEMBAHASAN}

\section{Kebijakan Negara-negara Lain}

Banyak negara telah mengenalkan atau mengadopsi program bauran untuk menyelamatkan sektor usaha kecil dan menengah atau UMKM (OECD, 2020). Pertama, memberikan subsidi gaji kepada UMKM yang tidak mampu membayar gaji pegawainya. Kedua, mendorong pengembangan inovasi wiraswasta agar dapat menyerap tenaga kerja yang menganggur. Ketiga, memberikan penangguhan penyelesaian kewajiban atau utang UMKM baik untuk kewajiban perpajakan maupun kewajiban pinjaman usaha. Keempat, memberikan pinjaman secara langsung kepada pelaku UMKM agar dapat memiliki modal yang cukup untuk mempertahankan bisnis. Kelima, mendorong digitalisasi usaha UMKM agar dapat tetap beroperasi dalam kondisi terdapat pembatasan pergerakan masyarakat. Tabel 3 menyajikan ringkasan penanganan COVID-19 pada beberapa negara. Instrumen fiskal seperti penangguhan pajak penghasilan (PPh) masih menjadi pilihan umum yang digunakan oleh banyak negara dalam mengatasi pandemi Covid19 (Febrantara, 2020).

Tabel 3. Upaya Penyelamatan untuk UMKM oleh Beberapa Negara

\begin{tabular}{|c|c|c|c|c|c|c|c|c|}
\hline \multirow[b]{2}{*}{ No } & \multirow[b]{2}{*}{ Negara } & \multirow{2}{*}{$\begin{array}{l}\text { Subsidi } \\
\text { Upah }\end{array}$} & \multirow{2}{*}{$\begin{array}{l}\text { Penumbuhan } \\
\text { Wiraswasta }\end{array}$} & \multicolumn{3}{|c|}{ Penangguhan } & \multirow{2}{*}{$\begin{array}{l}\text { Pinjaman } \\
\text { Langsung } \\
\text { UKM }\end{array}$} & \multirow[b]{2}{*}{ Digitalisasi } \\
\hline & & & & PPh & PPN & $\begin{array}{l}\text { Relaksasi } \\
\text { Pinjaman }\end{array}$ & & \\
\hline 1 & Malaysia & & & & & $\mathrm{v}$ & $\mathrm{v}$ & $\mathrm{v}$ \\
\hline 2 & Singapura & $\mathrm{v}$ & & $\mathrm{v}$ & & & $\mathrm{v}$ & \\
\hline 3 & Vietnam & & & v & & & & \\
\hline 4 & Amerika Serikat & $\mathrm{v}$ & $\mathrm{v}$ & $\mathrm{v}$ & & & $\mathrm{v}$ & \\
\hline 5 & Belanda & $\mathrm{v}$ & $v$ & $\mathrm{v}$ & $\mathrm{v}$ & $\mathrm{v}$ & & \\
\hline 6 & Cina & $\mathrm{v}$ & & $\mathrm{v}$ & & $\mathrm{v}$ & $\mathrm{v}$ & $\mathrm{v}$ \\
\hline 7 & Inggris & v & $\mathrm{v}$ & v & & $\mathrm{v}$ & $\mathrm{v}$ & \\
\hline 8 & Arab Saudi & & & & & $\mathrm{v}$ & $\mathrm{v}$ & \\
\hline 9 & Turki & $\mathrm{v}$ & & $\mathrm{v}$ & $\mathrm{v}$ & $\mathrm{v}$ & $\mathrm{v}$ & \\
\hline 10 & Jepang & $\mathrm{v}$ & & $\mathrm{v}$ & & & $\mathrm{v}$ & $\mathrm{v}$ \\
\hline 11 & Korea Selatan & $\mathrm{v}$ & $\mathrm{v}$ & & & $\mathrm{v}$ & & $\mathrm{v}$ \\
\hline 12 & Australia & $\mathrm{v}$ & $\mathrm{v}$ & $\mathrm{v}$ & & $\mathrm{v}$ & $\mathrm{v}$ & \\
\hline 13 & Italia & $\mathrm{v}$ & $\mathrm{v}$ & $\mathrm{v}$ & $\mathrm{v}$ & $\mathrm{v}$ & $\mathrm{v}$ & $\mathrm{v}$ \\
\hline
\end{tabular}

Sumber: Febrantara (2020) dan OECD (2020) 
Upaya mendorong wiraswasta juga dilakukan dengan pelaksanaan pelatihan tenaga kerja agar memiliki keterampilan kerja yag cukup. Selain dengan subsidi gaji dan pelatihan tenaga kerja, beberapa negara juga melakukan upaya intervensi dalam bidang pasar tenaga kerja pada sektor UMKM antara lain dilakukan dengan perubahan regulasi/tata kelola pasar tenaga kerja dan pengurangan jam kerja pekerja. (Gentilini et al., 2020). Intervensi melalui subsidi upah (wage subsidy) untuk sektor UMKM dilakukan oleh beberapa negara seperti China, Perancis, Jepang, Serbia, Thailand dan Venezuela (Gentilini et al., 2020). Tabel 4 menyajikan upaya penyelamatan UMKM pada beberapa negara melalui upaya intervensi pasar tenaga kerja.

Tabel 4. Intervensi Pasar Tenaga Kerja di Beberapa Negara

\begin{tabular}{ll}
\hline Bentuk Intervensi & Persentase (\%) \\
\hline Subsidi gaji/upah & 36 \\
Reaktifasi tenaga kerja melalui training & 11 \\
Penyesuaian regulasi/tata kelola pasar tenaga kerja & 11 \\
Pengurangan jam kerja & 3 \\
Total Program & $\mathbf{6 1}$ \\
\hline
\end{tabular}

Sumber: (Gentilini et al., 2020)

Otoritas pembuatan kebijakan di Cina melakukan intervensi berupa stimulus ekonomi untuk menstabilkan atau mempertahankan pertumbuhan ekonomi (Fernandes, 2020). Pasca pandemi COVID-19, bahkan tiga bulan setelah wabah, ekonomi Cina tidak akan beroperasi secara normal. UMKM menjadi kunci karena di hampir semua negara, UMKM mempekerjakan banyak tenaga produktif. Pengambilan kebijakan yang tepat untuk memulihkan perekonomian sangat menentukan, terutama berkaitan menjaga likuiditas UMKM, mendukung keluarga terdampak, reaksi dan kesiapan dunia usaha memulai kegiatan ekonominya (Fernandes, 2020). Pengambilan kebijakan juga sangat tergantung dari lamanya pengurangan aktifitas sosial atau lockdown.

Langkah kebijakan yang baik juga dicontohkan dari Arab Saudi yang mengedepankan serangkaian kebijakan terkoordinasi dengan tujuan utama melindungi manusia dan menjaga kestabilan ekonomi (Sikki, 2020). Pemerintah Arab Saudi memberikan keringanan bagi para pemilik bisnis dalam jangka waktu 3 bulan untuk menunda pembayaran PPN, Pajak Cukai, Pajak Penghasilan dan pengajuan pernyataan zakat dan pembayaran kewajiban lainnya (Sikki, 2020). Kementerian Keuangan Arab Saudi juga memberikan bantuan pembiayaan dalam bentuk pinjaman serta pembebasan dari pengembalian pinjaman beserta biayanya sampai akhir tahun 2020 dalam inisiatif program keberlanjutan perusahaan (Sikki, 2020).

Dernmark memberikan kompensasi kerugian sebesar 75\% terhadap para pelaku UMKM, yang memiliki jumlah karyawan di bawah 10 orang dan mengalami kerugian sekitar 30\% atau lebih (Febrantara, 2020). Italia membangun portal digital yang disediakan tanpa biaya kepada para UMKM agar dapat tetap menjalankan roda bisnis di masa pandemi (Febrantara, 2020).

Pemerintah USA merespons dengan program pinjaman lunak untuk beberapa sektor usaha, program ini memberikan uang tunai bagi mereka yang membutuhkan untuk mempertahankan pekerja, membayar sewa, dan membantu bisnis mereka hidup kembali (Baker \& Judge, 2020). Pemerintah USA perlu menemukan cara-cara baru dan kreatif untuk bekerja dengan perantara yang ada, termasuk bank dan pemberi pinjaman online, yang memiliki infrastruktur dan alat yang diperlukan untuk membantu usaha kecil mendapatkan pinjaman tambahan yang mereka butuhkan untuk bertahan hidup dan berkembang (Baker \& Judge, 2020). Memanfaatkan lembaga yang ada dapat meningkatkan kecepatan, skala, dan ruang lingkup respons pemerintah, semua kebijakan penting dilakukan dalam upaya mendukung bisnis kecil di USA (Baker \& Judge, 2020). 


\section{Kebijakan Penyelamatan UMKM oleh Indonesia}

Pada tanggal 25 Februari 2020, pemerintah Indonesia mengeluarkan paket kebijakan USD725 juta untuk insentif keuangan bagi berbagai sektor pariwisata, jasa penerbangan dan properti, serta penambahan subsidi dan pemotongan pajak (OECD, 2020). Terdapat lima skema perlindungan dan pemulihan koperasi dan UMKM di tengah pandemi Covid-19 (Kemenkop-UKM, 2020), yaitu: (a) pemberian bantuan sosial kepada pelaku usaha sektor UMKM yang miskin dan rentan, (b) insentif pajak bagi UMKM; (c) relaksasi dan restrukturisasi kredit bagi UMKM; (d) perluasan pembiayaan modal kerja UMKM; (d) menempatkan kementerian, BUMN dan Pemerintah Daerah sebagai penyangga produk UMKM; dan (e) pelatihan secara e-learning.

\section{Pemberian Bantuan Sosial}

Bantuan sosial diberikan kepada para pelaku UMKM yang masuk dalam kategori miskin dan rentan (Kemenkop-UKM, 2020). Termasuk dalam skema bantuan sosial ini adalah penurunan tarif listrik 50 persen untuk pelanggan listrik dengan kapasitas 450 watt lebih dari tiga bulan (Arifin, 2020), yang umumnya dapat merupakan para pekerja atau pelaku usaha UMKM. Kendala pemberian bansos tersebut adalah masih banyak penerima yang belum terdata secar detail.

\section{Insentif Perpajakan}

Pemberian insentif pajak bagi UMKM ini diberikan untuk UMKM dengan omset kurang dari Rp4,8 miliar per tahun (Kemenkop-UKM, 2020). Wujud stimulus untuk PPh adalah pengenaan tarif PPh sebesar nol persen diberikan selama enam bulan yaitu periode April s.d. September 2020. Namun menurut D. Setiawan (2020), fasilitas ini masih banyak belum dimanfaatkan oleh pelaku UMKM. Sampai dengan 29 Mei 2020, jumlah permohonan insentif pajak mencapai 375.913 pemohon. Dari jumlah pemohon tersebut, 345.640 atau sekitar 91,9\% permohonan dikabulkan.

\section{Relaksasi dan Restrukturisasi Kredit bagi UMKM}

Kebijakan ini merupakan kebijakan yang dikeluarkan pada tanggal 13 Maret 2020 sebagai respon nonfiskal berupa pelonggaran atau restrukturisasi pinjaman bank ke UMKM berbarengan dengan penyederhanaan proses sertifikasi untuk eksportir dan kemudahan impor bahan mentah (OECD, 2020). Pemerintah akan memberikan keringanan kredit di bawah Rp10 miliar khususnya bagi pekerja informal (ojek online, sopir taksi, pelaku UMKM, nelayan, penduduk dengan penghasilan harian) yang efektif berlaku pada bulan April 2020 (Maftuchan, 2020). Paket stimulus restrukturisasi kredit UKM tersebut pada beberapa pemerintah provinsi, terutama Jawa Tengah, dilengkapi dengan intervensi tambahan (OECD, 2020). Sejalan kebijakan tersebut, pada tanggal 19 Maret 2020, Bank Indonesia mengumumkan penurunan rasio persyaratan cadangan (reserve requirement ratio) sebesar 50 basis poin (bps) untuk bank-bank yang terlibat dalam pembiayaan UMKM, setelah pemotongan 50 basis poin (bps) di bulan sebelumnya untuk medukung kegiatan perdagangan (OECD, 2020). Bantuan keuangan kepada para pelaku UMKM juga dilakukan dengan mendorong sektor perbankan untuk memberikan pinjaman lunak kepada para pelaku UMKM dengan mekanisme yang ketat. (Pakpahan, 2020).

\section{Perluasan pembiayaan modal kerja UMKM}

Perluasan pembiayaan modal kerja UMKM ini dlakukan dengan mendorong perbankan untuk dapat memberikan kredit lunak kepada UMKM. Dengan demikian UMKM memiliki modal kerja yang cukup untuk dapat menjalan bisnisnya. Kebijakan ini perlu untuk menjaga likuiditas UMKM (Pakpahan, 2020). Program ini ditargetkan untuk 23 juta UMKM yang belum pernah mendapatkan pembiayaan dari perbankan dan lembaga keuangan. Setiawan (2020a) menyebutkan bahwa program perluasan pembiayaan ini diberikan baik untuk UMKM yang bersifat "bankable" maupun tidak "bankable".

\section{Penyediaan Penyangga Produk}

Produk koperasi dan UMKM di bidang pertanian, perikanan, kuliner dan indsutri rumah tangga perlu mendapatkan dukungan penyangga. Dengan demikian, terdapat kepastian bahwa produk UMKM akan terserap, sehingga koperasi dan UMKM akan dapat memiliki perputaran persediaan yang lebih baik. 
Kebijakan ini akan lebih terasa manfaatnya apabila diikuti dengan upaya peningkatan arus distribusi yang aman, misalnya dengan penyediaan fasilitas atau layanan e-commerce yang handal di daerah penyangga.

\section{Intervensi Pasar Tenaga Kerja UMKM melalui Pelatihan dengan Metode E-learning}

Indonesia melakukan intervensi dalam pasar tenaga kerja dengan melakukan pelatihan yang dimaksudkan mengaktifkan kembali pasar tenaga kerja melalui Kartu Prakerja yang diluncurkan pada April 2020. Program ini memberikan pelatihan bersubsidi yang bersifat skilling dan re-skilling bagi 5,6 juta tenaga kerja terdampak khususnya di sektor usaha kecil dan mikro (Gentilini et al., 2020). Peserta program kartu prakerja dapat merupakan pekerja sektor UMKM yang telah terkena pemutusan kerja maupun tenaga kerja baru yang belum mendapatkan pekerjaan. Kebijakan ini sejalan dengan kebijakan penumbuhan wiraswasta yang dilakukan oleh beberapa negara OECD seperti Amerika Serikat, Belanda, Inggris, Korea Selatan, Australia dan Italia (OECD, 2020).

\section{Penerapan Protokol Kesehatan di Dunia Usaha}

Kemenkes (2020) pada tanggal 20 Mei 2020 mengeluarkan ketentuan mengenai protokol pencegahan COVID-19 di area publik khususnya untuk setkor jasa dan perdagangan. Ketentuan tersebut berlaku bagi pengurus atau pengelola tempat kerja/pelaku usaha, pekerja, dan konsumen/pelanggan. Menurut Medialndonesia.Com (2020), langkah tersebut dianjurkan oleh Kementerian Koperasi dan UMKM antara lain dalam bentuk penggunaan masker baik oleh pelaku sektor UMKM maupun masyarakat sebagai pengguna produk atau jasa UMKM.

\section{Strategi Lain yang Perlu Diambil sebagai Pelengkap Kebijakan}

Sesuai dengan perkembangan implementasi kebijakan pemerintah untuk memberdayakan UMKM yang terdampak pandemi COVID-19, terdapat beberapa laangkah tambahan yang dapat diambil sebagai pelengkap kebijakan yang ada. Strategi pelengkap tersebut dapat berupa strategi jangka pendek maupun strategi jangka panjang.

\section{Strategi Jangka Pendek}

Strategi jangka pendek diperlukan agar kebijakan pemerintah untuk menyelamatkan UMKM saat ini dapat berjalan secara efektif selama dan sesudah pandemi COVID-19. Beberapa langkah atau strategi jangka pendek perlu digalakkan untuk mendukung langkah penyelamatan UMKM oleh pemerintah. Langkah tersebut berkaitan dengan penerapan protokol kesehatan yang ketat, pemberian peluang dan dorongan layanan digital sebagai pendukung UMKM, sosialisasi kepada asosiasi dan pelaku usaha, penyederhanaan proses administrasi, serta upaya mendorong perubahan strategi bisnis. Masing-masing strategi jangka pendek tersebut dijelaskan sebagai berikut. Pertama, UMKM perlu menjalankan protokol kesehatan secara ketat dalam menjalankan aktivitas ekonominya. Bahkan Pakpahan (2020) menyarankan agar potokol kesehatan yang ketat juga dapat diterapkan ketika pemerintah memberikan izin bagi UMKM untuk menjalankan aktivitasnya, artinya hanya UMKM yang memenuhi ketentuan protokol kesehatan yang diijinkan beroperasi. Kedua, Pemerintah dapat memberikan ruang dan dukungan bagi perkembangan layanan digital karena dapat mengurangi interaksi fisik namun proses transaksi dapat tetap terjadi. Pemerintah dapat menggandeng BUMN, BUMD atau perusahaan-perusahan ekspedisi untuk melakukan penghantaran produk-produk UMKM. Pemberian insentif bagi perusahaan-tersebut dapat dipertimbangkan, agar biaya pengiriman tidak menjadi tambahan biaya yang memberatkan penjual dan pembeli. Menurut Burhan (2020), saat pandemi ini pengguna jasa layanan antar makanan meningkat hingga 30\%. Digital marketing perlu diperkenalkan kepada pelaku UMKM untuk menjadi salah satu strategi promosi dan pemasaran yang efisien. Ketiga, Asosiasi pelaku usaha seperti Apindo, Kadin, dan IPMI perlu ikut aktif mensosialisasikan kebijakan pemerintah, dan mendorong agar seluruh stakeholder dalam bisnis UMKM mengambil peran terbaik. Keempat, Tidak kalah penting dari keberhasilan kebijakan pemerintah adalah upaya penyederhanaan proses administrasi terkait dengan kebijakan pelonggaran atau penundaan pembayaran kredit bagi UMKM. Kelima. Penguatan proses pemantauan dan evaluasi pelaksanaan program kerja pemberdayaan COVID-19. Kelima, Pemerintah melakukan pembinaan ke 
UMKM dengan mendorong inovasi dan berubahan strategi bisnis menyesuaikan situasi. Misal, UMKM yang awalnya berbisnis kuliner dapat merubah bisnis ke bahan baku makanan, mengingat saat ini orang lebih suka memasak sendiri makanan di rumah. Menurut Burhan (2020), setelah pandemi, order langsung di restoran turun dari $80 \%$ total transaksi menjadi $60 \%$ dari total transaksi.

\section{Strategi Jangka Panjang}

Strategi jangka panjang ditujukan untuk menjamin agar di masa mendatang UMKM dapat tetap bertahan menjadi pemain utama dalam perekonomian pasca pandemi COVID-19. Strategi jangka panjang tersebut terkait dengan upaya menyiapkan peta jalan pengembangan UMKM, membangun teknologi digital sebagai platform dalam proses bisnis UMKM, pengembangan model bisnis UMKM yang modern, serta mendorong kolaborasi pemerintah dengan korporasi dalam memberdayakan UMKM. Masing-masing strategi jangka panjang tersebut dijelaskan sebagai berikut. Pertama, Pemerintah perlu membuat peta jalan (road map) pengembangan UMKM dalam menghadapi dunia bisnis pasca COVID-19 secara khusus dan dunia bisnis secara umum. Para pelaku bisnis UMKM perlu diberi bekal mengenai pemahaman bentuk bisnis di era industri 4.0. Program Prakerja dapat digunakan sebagai pemantik upaya mengasah kemampuan pelaku UMKM dalam menghadapi era digitalisasi ke depan. Kedua, Penguatan penggunaan teknologi digital untuk mendukung aktivitas ekonomi UMKM. Upaya ini sebagai kelanjutan dari strategi jangka pendek, namun dalam strategi jangka panjang, teknologi digital harus menjadi platform utama dalam proses bisnis UMKM. Hal ini sejalan dengan pendapat Pakpahan (2020) yang menyebutkan bahwa ke depan UMKM dapat menggunakan teknologi digital untuk proses produksi, promosi produk, maupun menentukan pasar potensial untuk produknya. Ketiga, pemerintah dapat menyediakan model pembinaan UMKM dengan menggandeng institusi atau lembaga akademis bidang kewirausahaan dan manajemen bisnis agar UMKM dapat menjadi wujud nyata praktik bisnis sesuai dengan perkembangan dunia usaha. Penelitian Hadi (2020) di Yogyakarta menunjukkan bahwa praktik penggunaan model analisis seperti Business Model Canvas (BMC) dapat dipilih untuk merumuskan strategi terbaik dalam mengembangkan UMKM pasca COVID-19. Keempat, Pemerintah perlu menggandeng usaha besar dan korporasi baik milik swasta maupun pemerintah (BUMN) untuk dapat menyalurkan dana atau menyelenggarakan program Corporate Social Responsibililty (CSR). Perusahaan-perusahaan tersebut dapat membina UMKM sebagai mitra dalam lini bisnisnya, sehingga secara tidak langsung berdampak positif terhadap kesinambungan perusahaan itu sendiri sebagai pemberi CSR.

\section{SIMPULAN}

Berdasarkan penelitian tersebut di atas, dapat kita ambil kesimpulan bahwa sama seperti di hampir semua negara, sektor UMKM di Indonesia mengalami dampak dari Pandemi COVID-19. Dampak tersebut berturut adalah penurunan penjualan, kesulitan permodalan, hambatan distribusi produk, serta kesulitan bahan baku. Pemerintah telah mengeluarkan kebijakan dalam rangka memperdayakan UMKM dalam situasi pandemi COVID-Terdapat beberapa skema perlindungan UMKM yang dilakukan pemerintah yaitu (a) pemberian bantuan sosial kepada pelaku UMKM miskin dan rentan, (b) insentif pajak bagi UMKM; (c) relaksasi dan restrukturisasi kredit bagi UMKM; (d) perluasan pembiayaan modal kerja UMKM; (d) menempatkan kementerian, BUMN dan pemerintah Daerah sebagai penyangga produk UMKM; dan (e) pelatihan secara e-learning.

Untuk mendukung kebijakan pemerintah, beberapa strategi jangka pendek dan strategi jangka panjang perlu dipertimbangkan oleh pemerintah. Strategi jangka pendek berkaitan dengan penerapan protokol kesehatan yang ketat, memberi peluang dan dorongan layanan digital sebagai pendukung UMKM, sosialisasi asosiasi pelaku usaha, penyederhanaan proses administrasi, serta upaya mendorong perubahan strategi bisnis. Strategi jangka panjang berkaitan dengan upaya menyiapkan peta jalan pengembangan UMKM, membangun teknologi digital sebagai platform dalam proses bisnis UMKM, pengembangan model bisnis UMKM yang modern, serta mendorong kolaborasi pemerintah dengan korporasi dalam memberdayakan UMKM. 


\section{REFERENSI}

Abidin, M. (2015). Kebijakan Fiskal dan Peningkatan Peran Ekonomi UMKM. Retrieved from https://www.kemenkeu.go.id/publikasi/artikel-dan-opini/kebijakan-fiskal-dan-peningkatanperan-ekonomi-umkm/

Arifin, D. (2020). Jaringan Pengaman Sosial Kurangi Dampak Ekonomi Masyarakat di Tengah Pandemi COVID-19. Retrieved from https://bnpb.go.id/berita/jaring-pengaman-sosial-kurangi-dampakekonomi-masyarakatdi-tengah-pandemi-covid19

Baker, T., \& Judge, K. (2020). How to Help Small Businesses Survive COVID-19. Columbia Law and Economics Working Paper(620). Retrieved from http://dx.doi.org/10.2139/ssrn.3571460

$\begin{array}{lllll}\text { BNPB. (2020). Infografis Covid-19. } & \text { Retrieved }\end{array}$ https://loker.bnpb.go.id/s/GugusTugasCovid19?path=\%2FInfografis\%20Data

Burhan, F. (2020). Bisnis Anjlok Akibat Pandemi Corona, UMKM Bisa Uabh Strategi Usaha. Retrieved from https://katadata.co.id/berita/2020/04/15/bisnis-anjlok-akibat-pandemi-corona-umkm-bisaubah-strategi-usaha

Databoks. (2020). Pemerintah Beri Stimulus, Berapa Jumlah UMKM di Indonesia? Retrieved from https://databoks.katadata.co.id/datapublish/2020/04/08/pemerintah-beri-stimulus-berapajumlah-umkm-di-indonesia\#

Febrantara, D. (2020). Bagaimana Penanganan UKM di Berbagai Negara Saat Ada Pandemi Covid-19? DDTC Fiscal Research. Retrieved from https://drive.google.com/drive/folders/1MY31IOC3gWqEgzNkuJzqJnB9PV6qA2D

Fernandes, N. (2020). Economic effects of coronavirus outbreak (COVID-19) on the world economy. Available at SSRN 3557504.

Gentilini, U., Almenfi, M., Orton, I., \& Dale, P. (2020). Social protection and jobs responses to COVID-19: a real-time review of country measures. Live Document. World Bank, Washington, DC. http://www. ugogentilini. net/wp-content/uploads/2020/03/global-review-of-social-protection-responsestoCOVID-19-2. $\quad$ pdf. Retrieved from http://documents.worldbank.org/curated/en/377151587420790624/pdf/Social-Protection-andJobs-Responses-to-COVID-19-A-Real-Time-Review-of-Country-Measures-April-3-2020.pdf

Hadi, S. (2020). Revitalization Strategy for Small and Medium Enterprises after Corona Virus Disease Pandemic (Covid-19) in Yogyakarta. In.

Hadiwardoyo, W. (2020). Kerugian Ekonomi Nasional Akibat Pandemi Covid-19. Jurnal of Business and Enterpreneurship, Vol. 2 No. 2 April 2020. doi:10.24853/baskara.2.2.83-92

Hanoatubun, S. (2020). Dampak Covid-19 terhadap Prekonomian Indonesia. EduPsyCouns: Journal of Education, Psychology and Counseling, 2(1), 146-153.

Islam, A. (2020). Configuring a Quadruple Helix Innovation Model (QHIM) based blueprint for Malaysian SMEs to survive the crises happening by Covid-19. Emerald Open Res, 2.

Kemenkes. (2020). Surat Edaran No. HK.02.01/MENKES/335/2020 tentang Protokol Pencegahan Penularan COVID-19 di Tempat Kerja Sektor Jasa dan Perdagangan (Area Publik) dalam Mendukung Keberlangsungan Usaha. Jakarta 
Kemenkop-UKM. (2018). Perkembangan Data Usaha Mikro, Kecil, Menengah (UMKM) dan Usaha Besar (UB). Retrieved from http://www.depkop.go.id/uploads/laporan/1580223129 PERKEMBANGAN\%20DATA\%20USAHA \%20MIKRO,\%20KECIL,\%20MENENGAH\%20(UMKM)\%20DAN\%20USAHA\%20BESAR\%20(UB)\%20T AHUN\%202017\%20-\%202018.pdf

Kemenkop-UKM. (2020). Menkop dan UKM Paparkan Skema Pemulihan Ekonomi KUKM di Masa dan Pasca COVID-19. Retrieved from http://www.depkop.go.id/read/menkop-dan-ukm-paparkanskema-pemulihan-ekonomi-kumkm-di-masa-dan-pasca-covid-19

Maftuchan, A. (2020). Policy Brief 21-Program Tunai di Era COVID-19: Bantuan Tunai Korona atau Jaminan Penghasilan Semesta.

Medialndonesia.Com. (2020, 15 Mei 2020). Kemenkop Ajak Pelaku UMKM dan Masyarakat Taat Protokol Kesehatan. Media Indonesia. Retrieved from https://mediaindonesia.com/read/detail/313231kemenkopajak-pelaku-umkm-dan-masyarakat-taat-protokol-kesehatan

OECD. (2020). SME Policy Responses: Tackling Coronavirus (Covid-19) Contributing to A Global Effort. Retrieved from https://oecd.dam-broadcast.com/pm 7379119 119680-di6h3qgi4x.pdf

Pakpahan, A. K. (2020). COVID-19 dan Implikasi Bagi Usaha Mikro, Kecil, dan Menengah. Jurnal IImiah Hubungan Internasional, 59-64.

Prasetyo, A., \& Huda, M. (2019). Analisis Peranan Usaha Kecil dan Menengah Terhadap Penyerapan Tenaga Kerja di Kabupaten Kebumen. Fokus Bisnis: Media Pengkajian Manajemen dan Akuntansi, 18(1), 26-35.

Setiawan. (2020a). Jokowi Minta 23 Juta UMKM Diberi Bantuan Pembiayaan Modal Kerja. Retrieved from https://bisnis.tempo.co/read/1336881/jokowi-minta-23-juta-umkm-diberi-bantuan-pembiayaanmodal-kerja/full\&view=ok

Setiawan. (2020b). sebanyak 37.000 UMKM Terdampak Virus Corona. Retrieved from https://money.kompas.com/read/2020/04/17/051200426/sebanyak-37.000-umkm-terdampakvirus-corona

Setiawan, D. (2020). DJP: Insentif Pajak Ditanggung Pemerintah Belum Banyak Dipakai UMKM. DDTC News. Retrieved from https://news.ddtc.co.id/djp-insentif-pajak-ditanggung-pemerintah-belumbanyak-dipakai-umkm-21190?page $y=0$

Sikki, K. L. (2020). Kebijakan Ekonomi Arab Saudi Dalam Mengantisipasi Pandemi Covid-19. Journal of Islamic Civilization, 2(1), 8-16.

Susilawati, S., Falefi, R., \& Purwoko, A. (2020). Impact of COVID-19's Pandemic on the Economy of Indonesia. Budapest International Research and Critics Institute (BIRCl-Journal): Humanities and Social Sciences, 3(2), 1147-1156.

Undang-undang Nomor 20 tahun 2008 tentang Usaha Mikro, Kecil dan Menengah Pasal 1 Angka 1.

Wordometer. (2020). Covid-19 Coronavirus Cases. Retrieved from https://www.worldometers.info/coronavirus/ 